\title{
FIELD DETERMINED VARIATION OF THE UNSATURATED HYDRAULIC CONDUCTIVITY FUNCTIONS USING SIMPLIFIED ANALYSIS OF INTERNAL DRAINAGE EXPERIMENTS
}

\author{
M. M. VILLAGRA; P. MICHIELS ( $\dagger)$; R. HARTMANN \\ Department of Soil Physics, Faculty of Agriculture and Applied Biological Sciences, University Ghent, Coupure Links \\ 653, B-9000 Ghent - Belgium. \\ O.O.S. BACCHI; K. REICHARDT \\ Center for Nuclear Energy in Agriculture, CENA, P.O.B. 96, CEP: 13400-970 - Piracicaba,SP - Brasil.
}

\begin{abstract}
ARSTRACT: Experimentally determined values of unsaturated soil hydraulic conductivity are presented for an Alfisol of the county of Piracicaba, S.P., Brazil. Simultaneous measurements of soil water content and pressure head are made along a $125 \mathrm{~m}$ transect within an irrigated field during the internal drainage process. Calculations of the soil hydraulic conductivity were made using the instantaneous profile method (Watson, 1966) and the unit gradient method (LIBARDI et al., 1980). The spatial variability of the soil hydraulic conductivity manifested along the transect indicates the need to develop a field method to measure $K(\theta)$ within prescribed fiducial limits, taking into account quantitative evaluation of spatial and temporal variances associated with the mathematical model, instrument calibration and soil properties.
\end{abstract}

Key Words: soil variability, hydraulic conductivity.

\section{VARIAÇÃo da CONDUTTVIDADE HIDRÁULICA DO SOLO NÃo SATURADO DETERMINADA EM CONDIÇŌES DE CAMIPO UTILIZANDO ANÁLISES SIMPLIFICADAS DE EXPERIMENTOS DE DRENAGEM INTERNA}

\begin{abstract}
RESUMO: São apresentados dados experimentais de condutividade hidrálica do solo, para um Alfisol (terra roxa estruturada) do Município de Piracicaba,SP - Brasil. Medidas simultaneas de umidade do solo e de potencial total da água no solo foram realizadas ao longo de uma transeção de $125 \mathrm{~m}$, dentro de um campo irrigado, durante o processo de drenagem interna. Os cálculos de condutividade hidráulica foram feitos utilizando o método do perfil instantâneo (WATSON, 1966) e o método do gradiente unitário (LIBARDI et al., 1980). A variabilidade espacial da condutividade hidráulica do solo observada ao longo da transeção aponta a necessidade do desenvolvimento de método de campo para a medida de $K(\theta)$ dentro de limites preestabelecidos de precisão, levando em conta a medida quantitativa das variâncias temporal e espacial associadas ao modelo matemático, a calibração dos instrumentos e as propriedades do solo.
\end{abstract}

Descritores: variabilidade do solo, condutividade hidrálica.

\section{INTRODUCTION}

In irrigated areas, the water use efficiency by the crops is strongly affected by the water losses at the soil surface (evaporation) and at the bottom of the root zone (deep drainage).

While the evaporation losses can be reduced by optimizing the physical conditions of the soil (DE BOODT, 1991), the deep drainage losses remain potentially important. Moreover, deep drainage can cause the contamination of the groundwater with pollutants. From agricultural and environmental viewpoints, the question has been put forward how to quantify rates of drainage losses below the root zone. To analyze quantitatively this drainage process, we must study the physical characteristics of the soil at the bottom of the root zone. Hence, the hydraulic conductivity $\left(\mathrm{K}, \mathrm{mm} \mathrm{day}^{-1}\right)$ as a function of soil water content $\left(\theta, \mathrm{cm}^{3} \mathrm{~cm}^{-3}\right)$ or soil water pressure head $(\mathrm{h}, \mathrm{cm})$ has to be determined acurately. On the other hand, the natural variability and the heterogeneity of the unsaturated hydraulic conductivity functions should be taken into account in order to understand, assess or predict the distribution of leaching over an entire field typically treated uniformly with respect to 
cultivation practices. ÜNLÜ et al. (1990) present a characterization of the spatial variability of selected soil hydraulic properties, which is a major step to better understand the use of field data.

In this study, we characterize the local variation of the unsaturated hydraulic conductivity function at the $150 \mathrm{~cm}$ depth of 25 plots along a $125 \mathrm{~m}$ transect in the field. The available data of the internal drainage experiments that were carried out in the field were analyzed in two different ways to obtain the hydraulic conductivity functions at the $150 \mathrm{~cm}$ depth. In the first part, analytical calculations were incorporated in the instantaneous profile method that was formally presented by WATSON (1966). In the second part, approximations were used to simplify the internal drainage method of the unit gradient as suggested by LIBARDI et al.. (1980).

\section{MATERIALS AND METHODS}

The internal drainage experiments that were used to determine the hydraulic conductivity functions were carried out at the field station of the University of São Paulo, Piracicaba, S.P. Brazil. The textural analysis of this fine textured soil is summarized in TABLE 1. This deep, relative homogeneous "Dark Red Latosol" is known as a "Terra Roxa Estruturada" and is classified as a Rhodic Kandiudalf.

The experimental layout contained of 25 bare plots $(5 \times 5 \mathrm{~m})$ aligned on a $125 \mathrm{~m}$ transect of a fairly level portion of the experimental field. Each plot consisted of one aluminium access tube and two mercury manometer tensiometers. The volumetric moisture content $\theta(z, t)$ was measured at $25 \mathrm{~cm}$ depth intervals to a depth of $150 \mathrm{~cm}$ using a neutron probe. Soil water pressure heads $h(z, t)$ were measured with tensiometers installed at 135 and $165 \mathrm{~cm}$. The hydraulic head $\mathrm{H}(\mathrm{z}, \mathrm{t})$ was given by the sum of the soil water pressure head $h(z, t)$ and the gravitational head $-\mathrm{z}$ with $\mathrm{z}$ being the depth coordinate measured positively downward from the soil surface $(z=0)$.

Internal drainage experiments were performed simultaneously on each plot to determine the hydraulic conductivity function. The $5 \times 125 \mathrm{~m}$ soil transect of plots was irrigated with a sprinkler line during seven consecutive days. Although it was not possible to saturate the soil profile completely, the soil water content reached values that were greater than those naturally occurring in the field, permitting an internal drainage over a useful moisture content range. After irrigation, the soil was covered with stubble mulch to prevent evaporative losses during the subsequent internal drainage period. The internal drainage process of the soil profile was monitored by making simultaneous measurements of the soil water content and soil water pressure head over a period of 20 days. The time of measurement was considered to be nearly identical for all the plots because the measurements were carried out immediately one after the other.

The step by step processing of the raw field data of $\Theta(z, t)$ and $h(z, t)$ to obtain the hydraulic conductivity function $K(\theta)$ are well described in the literature (HILLEL et al., 1972, VAUCLIN and VACHAUD, 1967). The analysis of the data is time consuming, especially when multiple field experiments are carried out to take into account the spatial variation of $K(\theta)$. Computer programs like CARHYD (VACHAUD et al. 1990) are useful in calculating values of $K(\theta)$.

In this study, we used two different methods to determine the $K(\theta)$ values. In the first case, regression calculations of measured values of $\theta(z, t)$ and $h(z, t)$ were incorporated in the instantaneous profile method (WATSON, 1966). In the second case, a simplified version of unit gradient method was used (LIBARDI et al., 1980).

For the first case hydraulic conductivity at depth $\mathrm{L}(150 \mathrm{~cm})$ at any time is obtained by integrating the general transport equation (assuming one dimensional vertical downward flow and no flux through the soil surface or water uptake by plants). We have:

$$
K_{(\theta)}=\frac{\int_{0}^{L}\left(\frac{\partial \theta(z, t)}{\partial t}\right) d z}{\left[\frac{\partial H(z, t)}{\partial z}\right]_{L}}
$$

The numerator of this equation represents the soil water flux density at depth $\mathrm{L}$ and can be rewritten as follows:

$$
\int_{0}^{L}\left(\frac{\partial \theta(z, t)}{\partial t}\right) d z=\frac{\partial S_{L}(t)}{\partial t}
$$

with

$S_{L}(t)$ represents the amount of water stored at time $t$ in the soil profile to depth $L$. Experimental values of $S_{i}(t)$ were obtained from 


$$
S_{L}(t)=\int_{0}^{L} \theta(z, t) d z
$$

soil water content measurements. The integral of equation (3) was approximated numerically by applying the Simpson rule (HAVERKAMP et al., 1984):

$$
\begin{aligned}
S_{L}(t)= & \frac{1}{3}\left(\theta_{0}+4 \theta_{25}+2 \theta_{50}+4 \theta_{75}+\right. \\
& \left.+2 \theta_{100}+4 \theta_{125}+\theta_{150}\right) \cdot \Delta z
\end{aligned}
$$

where the subscripts represent the depths of the soil water content measurements, $t$ represents the time of measurement and $\Delta z$ equals $25 \mathrm{~cm}\left(\theta_{0}\right.$ was assumed to be equal to $\theta_{25}$ owing to the difficulty of measuring $\Theta_{0}$ with the neutron probe).

To obtain a simple expression for the dependence of $S_{L}$ with $t$, a semi-logarithmic equation was fitted through the experimental values of $S_{L}(t)$ :

$$
S_{L}(t)=a+b \ln t
$$

The numerator of equation 1 was obtained by taking the time derivative of equation(5):

$$
\frac{\partial S_{L}(t)}{\partial t}=\frac{b}{t}
$$

From the tensiometer readings experimental values of $(\partial \mathrm{H} / \partial \mathrm{z})_{L}$ (the denominator of equation 1) were numerically approximated by:

$$
\left[\frac{\partial H(z, t)}{\partial z}\right]_{L}=\frac{H_{165}(t)-H_{135}(t)}{\Delta z}
$$

where the subscripts represent the depths of the soil water pressure head measurements, and $\Delta z$ is equal to $30 \mathrm{~cm}$. The experimental values of $\mathrm{H}_{135}(\mathrm{t})$ and $\mathrm{H}_{165}(\mathrm{t})$ were smoothed by regression with

$$
\begin{aligned}
& H_{135}(t)=c_{1}+d_{1} \ln t \\
& H_{165}(t)=c_{2}+d_{2} \ln t
\end{aligned}
$$

Substituting equations 8 and 9 in equation 7, one obtains

Sci. agric., Piracicaba, 51(1):113-122, jan./abr., 1994

$$
\left[\frac{\partial H(z, t)}{\partial z}\right]_{2}=c^{\prime}+d^{\prime} \ln t
$$

where, $c^{\prime}=\left[\left(C_{2}-C_{1}\right) / 30\right]$ and $d^{\prime}=\left[\left(d_{2}-d_{1}\right) / 30\right]$.

If indeed, a unit hydraulic head gradient exists during the time of an internal drainage experiment, the coefficients of equation 10 become $c^{\prime}=-1$ and $d^{\prime}=0$.

Finally, when equations 6 and 10 are substituted in equation 1 , one obtains

$$
K_{\theta}(t)=\frac{b / t}{c^{\prime}+d^{\prime} \ln t}
$$

which is used for calculating $K$ values at any time during the internal drainage experiment. To determine the corresponding $\Theta$ value, experimental measurements of $\Theta(t)$ at depth $L$ were fitted to the regression equation

$$
\Theta(t)=\theta_{0}+f \ln t
$$

where $\theta_{0}$ is the initial value of $\theta$ at $t=0$.

The $K(\theta)$ relationship was expressed as an exponential equation, which is in agreement with the use of a logarithmic equation for the $S_{\mathrm{L}}(t)$ data (VAUCLIN and VACHAUD, 1967):

$$
K(\theta)=K_{0} \exp \left(\gamma\left(\theta-\theta_{0}\right)\right)
$$

where $K_{0}=\mathbf{K}\left(\theta_{0}\right)$.

The parameters $K_{0}$ and $\gamma$ were estimated by linear regression techniques, using the $K$ and $\theta$ values obtained from equation 11 and 12 , for same values of $t$.

In the second method, the approximations of LIBARDI et al. (1980) were used to determine the hydraulic conductivity function. Three assumptions were made:

i. The only force causing internal drainage is gravity. In other words, a unit hydraulic head gradient exists with the soil water pressure head gradient being zero. Hence,

$$
\left[\frac{\partial H(z, t)}{\partial z}\right]_{L}=-1
$$

ii. The average soil water content in the soil profile to depth $L(\theta)$ is linearly related to the soil water content at depth $L(\theta)$ by the relation 


$$
\Theta^{*}(t)=p+q \theta(t)
$$

iii. $K$ is related to $\theta$ by equation 13 .

With these three assumptions, the integral of equation 1 , for large $t$, yields for depth $L$

$$
\Theta_{0}-\Theta=\frac{1}{\gamma} \ln \left(\frac{\gamma K_{0}}{q L}\right)+\frac{1}{\gamma} \ln t
$$

By fitting this regression equation to the experimental $\theta$ and $t$ values, the parameters $\mathrm{K}_{0}$ and $\gamma$ of equation 13 are determined. The reciprocal value of the slope of equation 16 yields $\gamma$, while the intercept is used to calculate $\mathrm{K}_{0}$ with known values of $\gamma, L$ and $q$.

Inasmach as tensiometer data were available, the K(h) relationship could also be established, what was done only for the first method since the second neglects the use of $h$. To determine the value of $h$ at the $150-\mathrm{cm}$ depth a semi-logarithmic equation was fitted through the average values of $h_{135}(t)$ and $h_{165}(t)$, representing $h_{150}(t)$ :

$$
h_{150}(t)=m+n \ln t
$$

The $K(h)$ relationship was expressed as an exponential model:

$$
K(h)=\alpha \exp (\beta h)
$$

\section{RESULTS AND DISCUSSION}

Figures 1 and 2 give examples of the measured values of soil moisture content $(\theta)$ and soil water pressure heads (h) for the 25 locations and three different days of internal drainage. The variability of both $\theta$ and $h$ in space is fairly TABLE 1 in time. Coefficients of variation in space for $\theta$ and $\mathrm{h}$ were about $4 \%$ and $6 \%$, respectively.

First Analysis (instantaneous profile): In figures 3,4 and 5 , an overview is given how the raw data of location 1 were treated in the first analysis to obtain the hydraulic conductivity functions. In figure 3 it is visualized how well the experimental values of $S_{L}(t)$ fit to the proposed semi-logarithmic regression equation (Eq. 5) at location 1 . The use of this equation was possible for this particular soil since the profile drains uniformly. The initial soil water storage down to $150 \mathrm{~cm}$ depth was 548.8 $\mathrm{mm}$ (coeff. a). The decrease in soil water storage down to $150 \mathrm{~cm}$ depth expressed by the $\mathrm{b}$ coefficient, was only $13 \mathrm{~mm}$ per unit ln of time. Similar values of $b$ were obtained for the other locations, with a maximum of $16 \mathrm{~mm}$ location 4 and a minimum of $9 \mathrm{~mm}$ in location 24. The correlation coefficient of equation 5 was always greater than 0.89 for all locations.

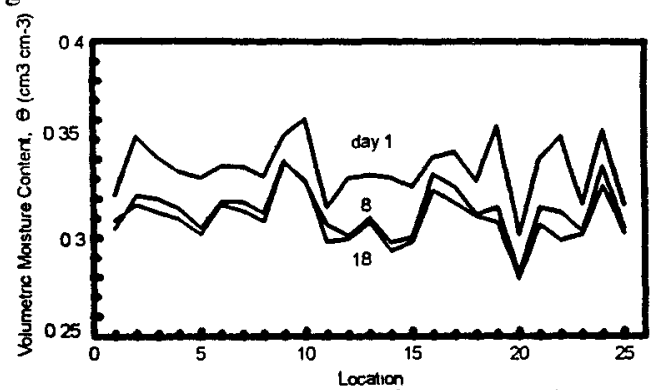

Figure 1 - Soil water content $(\Theta)$ variation in space and time for days 1,8 and 18 , during the internal drainage process, at the depth of $150 \mathrm{~cm}$.

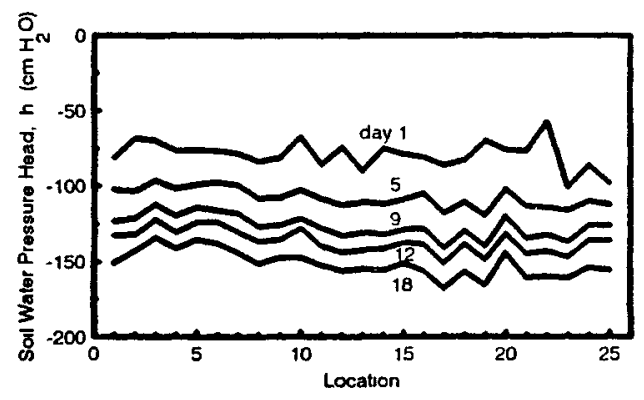

Figure 2 - Soil water pressure head (h) variation in space and time for days $1,5,9,12$ and 18 during the internal drainage process, at the depth of $150 \mathrm{~cm}$, taken as the average of 135 and $165 \mathrm{~cm}$ depth data.

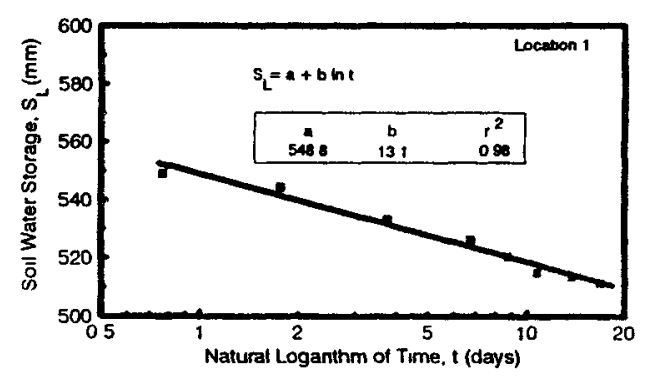

Figure 3 - Experimental (data points) and calculated (line) data of the soil water storage (from soil surface to $150 \mathrm{~cm}$ depth) as a function of the natural logarithm of time (equation 5). 


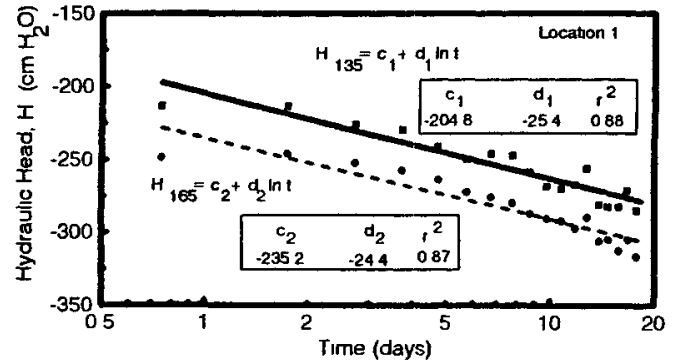

Figure 4 - Experimental (data points) and calculated (lines) data of the hydraulic head at 135 and $165 \mathrm{~cm}$ depth as a function of the natural logarithm of time (equations 8 and 9).

The application of the semi-logarithmic equations (Eq. 8 and 9) to fit the experimental data of hydraulic head values at $135 \mathrm{~cm}$ and $165 \mathrm{~cm}$ depths was also successful for all the locations of the transect. The fitting of this equation for location 1 is illustrated in figure 4. For all the locations, the regression coefficients were always greater than 0.90 for the two considered depths. For all the locations studied, the slopes of equations 8 and $9\left(d_{1}, d_{2}\right)$ were comparable to each other, while the intercepts $\left(c_{1}, c_{2}\right)$ showed, as expected for a unit gradient, a difference of about -30 . TABLE 2 summarizes the values of c'and d' for all the locations. These values indicate that the total hydraulic head gradients were close to unity for all tha locations during the whole experimental drainage period (20 days). Only plot number 20 deviated strongly.

Figure 5 shows the exponential decrease of $K$ for location 1: from $17 \mathrm{~mm}^{-d a y^{-1}}$ in the first day to less than 1 in the last day of the internal drainage period (20 days). Similar values were found for the other locations on the transect with a maximum reduction in $\mathrm{K}$ of 28 times between the first and the last day of the experiment.

The use of the semi-logarithmic equations (Eq. 12 and 17) to fit values of $\theta$ and $h$ showed large correlation coefficients in all the cases. For location 1 they were 0.85 and 0.88 , respectively. The $\theta$ values for location 1 decreased only $1.5 \%$ from the initial value during the experimental period. The same tendency was observed for other plots with maximum of $5 \%$ and minimum of $0.3 \%$ during the same period. Larger differences of $h$ values were observed between the first and the last day of the experiment for location $1\left(-24.9 \mathrm{~cm} \mathrm{H}_{2} \mathrm{O}\right.$, a reduction of $35 \%$ of the initial value). The percentage of reduction for the other plots varied from $52 \%$ to $26 \%$ during the 20 day period.

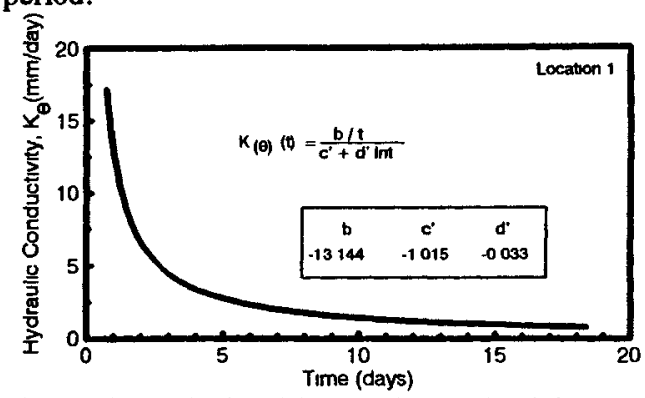

Figure 5 - Calculated hydraulic conductivity as a function of time (equation 11).

$K_{(\theta)}(t)$ values for all the 25 plots were calculated applying equation 11.

Regressions of $\ln \mathrm{K}_{(\theta)}(\mathrm{t})$ (Figure 6) values with corresponding $\theta(t)$ values yielded estimatives of $K_{0}$ and $\gamma$. In a similar way, regressions of $K_{(\theta)}(t)$ values with corresponding $h(t)$ values yielded estimatives of $\alpha$ and $\beta$. Data are presented in TABLE 3.

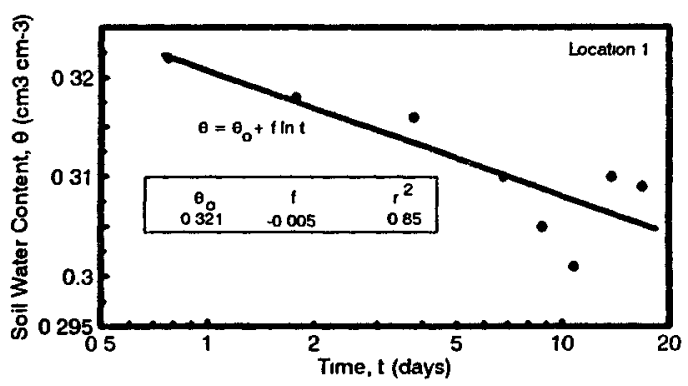

Figure 6 - Experimental (data points) and calculated (line) data of the soil water content at $150 \mathrm{~cm}$ depth in function of time (equation 12).

Second Analysis (unit gradient): The first assumption of the second analysis was approximately fulfilled. Coefficients $c^{\prime}$ and d', shown in TABLE 2, were close to -1 and zero, respectively, indicating slight deviations of the unit gradient with time, which is in agreement with REICHARDT (1993) who indicated that unit gradients cannot systematically occur.

With the value of the regression coefficient being greater than 0.9 except for 6 locations the second assumption is considered a reality. Coefficients $p$ and $q$ of equation 15 given for each location are presented in TABLE 2. 
TABLE 1 - Textural analysis of the soil profile.

\begin{tabular}{cccc}
\hline \hline Depth (cm) & Clay (\%) & Silt (\%) & Sand (\%) \\
\hline \hline $0-10$ & 67 & 8 & 25 \\
$10-37$ & 65 & 7 & 28 \\
$37-107$ & 60 & 7 & 33 \\
$107-187$ & 64 & 8 & 28 \\
\hline \hline
\end{tabular}

The third assumption built into the method of LIBARDI et al.. (1980) cannot be tested directly. Based upon the large regression coefficients of $\ln K$ versus $\theta$ in the first analysis, the assumption is considered as fulfilled. The values of $K_{0}$ and $\gamma$ are also found in TABLE 3 .

Comparison of $K(\theta)$ by the first and the second analyses: Figures 7 and 8 are regressions of $K_{0}$ and $\gamma$, for the instantaneous profile versus unit gradient, respectively. The low regression coefficient obtained for the comparison of $\mathrm{K}_{0}$ values showed that the methods are not equivalent (VILLAGRA, 1991) and suggest that $K_{0}$ should preferentially be measured directly during the infiltration test. On the other hand, for the purpose of this study, $K_{0}$ represents only a parameter of the $K(\Theta)$ relation. The high regression coefficient obtained for $\gamma$ data show that simple methods like LIBARDI et al..(1980) can be very useful for the estimation of $K(\theta)$ functions.

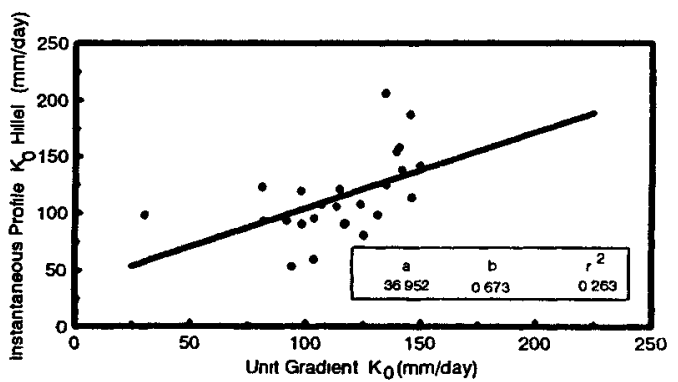

Figure 7 - Regression for $\mathrm{K}_{0}$ data obtained by the instantaneous profile and unit gradient methods.
Applying the methodology proposed by WARRICK \& NIELSEN (1980), based on the Central Limit theorem, it was found that $\mathrm{K}_{0}$ and $\gamma$ values can be estimated using only 25 plots if the error in the estimation of the new mean is greater than $10 \%$ at a confidence level of $10 \%$.

For more accurate estimations it would be necessary to consider a much great number of locations. This leads to the conclusion that 25 observation points make too small sample. It has to be recognized, however, that the experimental effort to perform one internal drainage test is great, so that numbers much greater than 25 become prohibitive.

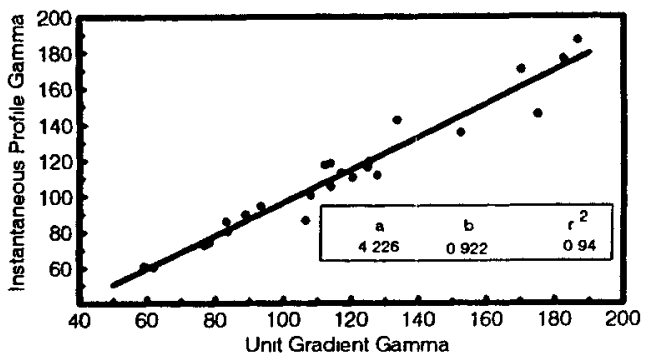

Figure 8 - Regression for gamma data obtained by the instantaneous profile and unit gradient methods.

Application of the $K(\theta), K(h)$ functions to estimate the deep drainage: As stated before, an accurated estimation of a $\mathbf{K}$ value for a given soil condition is very difficult, mainly due to errors in $\theta$ or $h$ estimation and to the exponential character of the $\mathrm{K}$ relations. Spatial variability, as shown in TABLE 2, plays a significant role. As an example TABLE 4 shows $K$ values used to estimate drainage flux densities on $13 / 2 / 90$, a sample day in which drainage below root zone was significant. 
TABLE 2 - Internal drainage parameters for hydraulic conductivity calculation, for the 25 plots (equat.10 and 15).

\begin{tabular}{|c|c|c|c|c|c|}
\hline \multirow{2}{*}{$\begin{array}{c}\text { PLOT } \\
\text { Nr. }\end{array}$} & \multicolumn{2}{|c|}{$\Delta \mathbf{H} / \mathbf{\Delta z}$} & \multicolumn{3}{|c|}{$\theta^{*}=p+q \theta$} \\
\hline & c' $^{\prime}$ & d' & $p$ & $q$ & $r$ \\
\hline 1 & -1.015 & 0.033 & -0.022 & 1.20 & 0.86 \\
\hline 2 & -1.002 & -0.035 & 0.092 & 0.78 & 0.87 \\
\hline 3 & -0.962 & 0.045 & 0.050 & 0.89 & 0.95 \\
\hline 4 & -1.157 & 0.079 & -0.002 & 1.11 & 0.96 \\
\hline 5 & -0.934 & -0.011 & 0.080 & 0.87 & 0.99 \\
\hline 6 & -1.032 & 0.076 & 0.025 & 0.99 & 0.96 \\
\hline 7 & -1.282 & 0.038 & 0.013 & 1.02 & 0.98 \\
\hline 8 & -0.807 & -0.060 & -0.031 & 1.20 & 0.96 \\
\hline 9 & -1.057 & -0.001 & -0.101 & 1.30 & 0.91 \\
\hline 10 & -1.213 & -0.016 & 0.126 & 0.67 & 0.96 \\
\hline 11 & -1.022 & 0.107 & 0.093 & 0.84 & 0.88 \\
\hline 12 & -1.046 & 0.051 & 0.222 & 0.42 & 0.79 \\
\hline 13 & -1.369 & 0.088 & 0.067 & 0.90 & 0.95 \\
\hline 14 & -0.956 & 0.045 & 0.102 & 0.78 & 0.98 \\
\hline 15 & -1.162 & 0.049 & 0.261 & 0.25 & 0.57 \\
\hline 16 & -0.987 & 0.093 & -0.005 & 1.06 & 0.93 \\
\hline 17 & -0.887 & 0.132 & 0.067 & 0.83 & 0.97 \\
\hline 18 & -1.335 & 0.082 & 0.048 & 0.97 & 0.92 \\
\hline 19 & -0.976 & 0.024 & 0.157 & 0.59 & 0.99 \\
\hline 20 & -2.022 & -0.090 & 0.082 & 0.79 & 0.97 \\
\hline 21 & -1.050 & 0.037 & 0.097 & 0.75 & 0.98 \\
\hline 22 & -0.848 & -0.029 & 0.159 & 0.57 & 0.99 \\
\hline 23 & -1.351 & 0.183 & 0.001 & 1.10 & 0.91 \\
\hline 24 & -1.043 & -0.055 & 0.134 & 0.61 & 0.93 \\
\hline 25 & -1.099 & -0.001 & -0.028 & 1.15 & 0.87 \\
\hline Mean & -1.108 & 0.035 & & & \\
\hline Std.Dev. & 0.243 & 0.064 & & & \\
\hline Var. & 0.059 & 0.004 & & & \\
\hline C.V.(\%) & 22 & 185 & & & \\
\hline
\end{tabular}

Sci. agric., Piracicaba, 51(1):113-122, jan./abr., 1994 
TABLE 3 - Values of $K_{0}$ and $\gamma$ for the instantaneous profile (equation 13) and unit gradient (equations 16) and $\alpha$ and $B$ coefficients (equation 18).

\begin{tabular}{|c|c|c|c|c|c|c|}
\hline \multirow{3}{*}{$\begin{array}{c}\text { PLOT } \\
\mathrm{Nr} . \\
\end{array}$} & \multicolumn{6}{|c|}{ METHOD } \\
\hline & \multicolumn{4}{|c|}{ Instantaneous Profile } & \multicolumn{2}{|c|}{ Unit Gradient } \\
\hline & $\mathrm{K}_{0}(\mathrm{~mm} / \mathrm{d})$ & $\gamma$ & $\alpha$ & B & $\mathrm{K}_{0}(\mathrm{~mm} / \mathrm{d})$ & $\gamma$ \\
\hline 1 & 119.72 & 176.44 & 194.81 & 0.039 & 98.29 & 182.65 \\
\hline 2 & 158.29 & 86.07 & 207.08 & 0.040 & 140.69 & 83.26 \\
\hline 3 & 107.51 & 118.71 & 128.27 & 0.039 & 107.07 & 124.88 \\
\hline 4 & 113.91 & 105.46 & 152.11 & 0.036 & 146.34 & 113.98 \\
\hline 5 & 154.30 & 94.49 & 278.95 & 0.044 & 139.46 & 93.37 \\
\hline 6 & 107.82 & 110.56 & 179.71 & 0.039 & 123.97 & 120.36 \\
\hline 7 & 98.53 & 113.27 & 132.71 & 0.038 & 131.34 & 116.90 \\
\hline 8 & 206.15 & 142.60 & 389.74 & 0.042 & 134.65 & 133.55 \\
\hline 9 & 121.33 & 170.46 & 166.12 & 0.038 & 114.92 & 170.24 \\
\hline 10 & 106.01 & 90.06 & 93.89 & 0.036 & 113.71 & 88.91 \\
\hline 11 & 90.67 & 112.04 & 137.45 & 0.033 & 98.75 & 127.57 \\
\hline 12 & 123.26 & 72.80 & 128.93 & 0.032 & 81.37 & 76.84 \\
\hline 13 & 80.90 & 100.45 & 165.52 & 0.037 & 125.55 & 108.05 \\
\hline 14 & 142.33 & 74.40 & 177.40 & 0.034 & 149.83 & 78.37 \\
\hline 15 & 98.46 & 119.52 & 122.20 & 0.035 & 30.41 & 125.06 \\
\hline 16 & 95.76 & 135.82 & 105.15 & 0.031 & 103.92 & 152.38 \\
\hline 17 & 91.21 & 86.57 & 120.02 & 0.027 & 117.44 & 106.57 \\
\hline 18 & 90.70 & 116.27 & 126.71 & 0.034 & 117.06 & 124.67 \\
\hline 19 & 138.15 & 60.31 & 131.66 & 0.030 & 142.06 & 61.89 \\
\hline 20 & 60.06 & 118.58 & 70.34 & 0.040 & 103.90 & 113.80 \\
\hline 21 & 124.88 & 80.56 & 118.43 & 0.031 & 135.16 & 83.64 \\
\hline 22 & 187.74 & 61.16 & 126.93 & 0.031 & 145.57 & 59.23 \\
\hline 23 & 53.62 & 145.77 & 133.80 & 0.034 & 94.48 & 174.97 \\
\hline 24 & 93.39 & 117.70 & 217.40 & 0.043 & 82.17 & 112.16 \\
\hline 25 & 93.35 & 186.83 & 469.76 & 0.046 & 92.12 & 186.60 \\
\hline Mean & 114.38 & 111.88 & 170.01 & 0.036 & 114.81 & 116.94 \\
\hline Std.Dev. & 35.33 & 33.16 & 89.88 & 0.005 & 25.98 & 36.71 \\
\hline Var. & 1248.11 & 1099.66 & 8079.08 & $2.2 \mathrm{E}-05$ & 931.22 & 1347.61 \\
\hline V.C.(\%) & 31 & 30 & 53 & 13 & 23 & 31 \\
\hline
\end{tabular}


TABLE 4 - Values of $K$ estimated from $K(\theta)$ and $K(h)$ relations, for each of the 25 experimental plots, during the day $13 / 02 / 90$.

\begin{tabular}{|c|c|c|c|c|c|}
\hline \multicolumn{3}{|c|}{$13 / 2 / 90$} & \multicolumn{3}{|c|}{ HYDRAULIC CONDUCTIVITY $(\mathrm{mm} / \mathrm{d})$} \\
\hline PLOT & $\theta_{150 \mathrm{~cm}}$ & $h_{150 \mathrm{~cm}}$ & Instantan. & Profile & Unit Gradient \\
\hline Nr. & $\left(\mathrm{cm}^{3} \cdot \mathrm{cm}^{-3}\right)$ & $\left(\mathrm{cm} \mathrm{H}_{2} \mathrm{O}\right)$ & $\mathbf{K}(\theta)$ & $\mathbf{K}(\mathrm{h})$ & $\mathbf{K}(\theta)$ \\
\hline 1 & 0.318 & -99.7 & 8.576 & 4.089 & 6.417 \\
\hline 2 & 0.326 & -98.6 & 1.841 & 3.982 & 1.893 \\
\hline 3 & 0.330 & -91.7 & 5.187 & 3.600 & 4.413 \\
\hline 4 & 0.324 & -105.5 & 4.509 & 3.329 & 4.462 \\
\hline 5 & 0.316 & -98.7 & 3.979 & 3.549 & 3.755 \\
\hline 6 & 0.331 & -101.7 & 4.619 & 3.300 & 4.017 \\
\hline 7 & 0.332 & -89.7 & 5.495 & 4.319 & 6.678 \\
\hline 8 & 0.324 & -107.0 & 6.234 & 4.347 & 5.085 \\
\hline 9 & 0.348 & -96.1 & 4.248 & 4.298 & 4.042 \\
\hline 10 & 0.346 & -106.9 & 2.627 & 2.006 & 2.954 \\
\hline 11 & 0.312 & -115.1 & 5.305 & 3.002 & 3.899 \\
\hline 12 & 0.318 & -115.1 & 1.571 & 3.299 & 0.814 \\
\hline 13 & 0.324 & -116.2 & 4.191 & 2.264 & 5.200 \\
\hline 14 & 0.308 & -104.3 & 3.762 & 5.348 & 3.263 \\
\hline 15 & 0.315 & -109.4 & 2.152 & 2.717 & 0.557 \\
\hline 16 & 0.341 & -104.8 & 8.333 & 3.894 & 6.715 \\
\hline 17 & 0.329 & -116.2 & 4.211 & 4.946 & 2.664 \\
\hline 18 & 0.315 & -105.5 & 1.992 & 3.354 & 1.950 \\
\hline 19 & 0.324 & -117.0 & 2.838 & 3.719 & 2.636 \\
\hline 20 & 0.292 & -100.5 & 1.262 & 1.298 & 2.552 \\
\hline 21 & 0.327 & -114.5 & 4.534 & 3.365 & 4.323 \\
\hline 22 & 0.326 & -112.1 & 4.651 & 3.724 & 4.052 \\
\hline 23 & 0.314 & -114.3 & 4.039 & 2.744 & 4.241 \\
\hline 24 & 0.347 & -105.9 & 3.487 & 2.374 & 3.581 \\
\hline 25 & 0.323 & -113.5 & 20.397 & 2.498 & 20.166 \\
\hline Mean & 0.325 & -106.4 & 4.720 & 3.415 & 4.4 \\
\hline Std. Dev. & 0.013 & 7.8 & 3.379 & 0.917 & 3.6 \\
\hline Var. & $1.6 \mathrm{E}-04$ & 60.5 & 11.418 & 0.826 & 12.8 \\
\hline V.C. $\%$ & 4 & 7 & 72 & 27 & 82 \\
\hline
\end{tabular}


Data of TABLE 4 show that for this specific day $K$ values for the instantaneous profile and unit gradient methods, using $\theta$ as independent variable show a coefficient of variation of the order of $75 \%$, which is substantial. On the other hand, the averages of $K$ for the 25 replicates are identical at a $1 \%$ interval of confidence. For the instantaneous profile method using $h$ as the independent variable, the coefficient of variation is reduced to $27 \%$ and the average $\mathrm{K}$ is significantly different from the former. These results indicate the great difficulty in using Darcy's equation to estimate soil water fluxes under field conditions. REICHARDT et al. (1993) and VILLAGRA et al. (1994) discuss these aspects in more detail.

\section{REFERENCES}

DE BOODT, M.F. Applications of polymeric substances as physical soil conditioners. In: De Boodt, M.F.: Hayes, M.; Herbillon, A. (Ed.), Soil colloids and their associations in aggregates. New York: Plenum Publishing Corporation, 1991, p.517-556.

HAVERKAMP, R.; VAUCLIN, M.: VACHAUD, G. Error analysis in estimating soil water content from neutron probe measurements: 1 . Local standpoint. Soil Science, Baltimore, v.137, p.78-90, 1984.

HILLEL, D.; KRENTOS, V.D.; STYLIANOU, Y. Procedure and test of an internal drainage method for measuring soil hydraulic characteristics in situ. Soil Science, Baltimore v.114, p.395-400, 1972.

LIBARDI, P.L.; REICHARDT, K.; NIELSEN, D.R.; BIGGAR, J.W. Simple field methods for estimating soil hydraulic conductivity. Soil Science Society of American Journal, Madison, v.44, p.3-7, 1980.

REICHARDT, $K$. Unit gradient in internal drainage ex periments for hydraulic conductivity determination. Scientia Agricola, Piracicaba, v.50, n.1, p.151-153, 1993.
REICHARDT, K.; BACCHI, O.O.S.; VILLAGRA, M.M. Estimativa de fluxos de água em solos não saturados. Bragantia, Campinas, v.52, n.1, p.83-87, 1993.

ÜNLÜ, K.; NIELSEN, D.R.; BIGGAR, J.W.; MORKOC, F. Statistical parameters characterizing the spatial variability of selected soil hydraulic properties. Soil Science Society of American Jourual, Madison, v.54, p.1537-1547, 1990.

VACHAUD, G.; VAUCLIN, M.; LATY., R. Carhyd, a computer-aided system for characterisation of the hydraulic conductivity of field soils. Soil Techmology, Cremlingen, v.3, p.131-144, 1990.

VAUCLIN, M.; VACHAUD, G. Caractérisation hydrodynamique des sols: analyze simplifiée des essais de drainage interne. Paris, Agronomie, 1967, p.647655 .

VILLAGRA, M.M. Variation in space and time of the hydrological components of the water balance: a study on an oxisol in Brazil. Belgium, 1991, 134p. Ph.D. thesis, University of Gent, Belgium.

VILLAGRA, M.M.; BACCHI, O.O.S.; TUON; R.L.; REICHARDT, $K$. Difficulties of estimating evapotranspiration from the water balance equation. Accepted by Agricultural and Forest Meteorology. Amsterdam, 1994.

WARRICK, A.W.; NIELSEN, D.R. Spatial variability of physical properties in the field. In: HILLEL. D. (Ed.), Applications of soil physics, New York: Academic Press, 1980. 385p.

WATSON, K.K. An instantaneous profile method for determining the hydraulic conductivity of unsaturated porous materials. Water Resources Research, Washington, v.2, p.709-715, 1966.

Enviado para publicação em 16.09 .93

Aceito para publicação em 10.02.94 